\title{
From Goods-dominant logic to Service-dominant logic
}

\author{
Tibor Zsigmond ${ }^{1 *}$, Annamária Zsigmondová1 ${ }^{1}$ and Renáta Machová ${ }^{1}$ \\ ${ }^{1} \mathrm{~J}$. Selye University, Faculty of Economics and Informatics, Department of Management, 94501 \\ Komárno, Slovakia
}

\begin{abstract}
In recent decades, the role of consumers in the marketing process has become more valuable to marketers. The previous theory - which focused only on the product itself and the services - has now become completely obsolete. This approach is called GDL, which is an acronym that stands for "Goods-dominant logic". The need for a paradigm shift has also been recognized by professionals, so they have increasingly begun to develop theories that put customers at the center. This shift did not occur from one moment to the next. With the development of newer and newer theories, the theory that changed the basic direction of marketing appeared by the end of the 2000s. This new paradigm is linked to researchers Lusch and Vargo. Their study titled "Evolving to a New Dominant Logic for Marketing" was published in 2004 in a professional journal called Journal of Marketing. The new policy is now called Service-dominant logic, abbreviated SDL. However, this theory is still not fully accepted. In some cases, shortcomings can be identified, mainly in terms of practical implementation. Furthermore, some research show that some elements or tools of the previous theory - GDL - cannot be completely omitted due to their simple applicability.
\end{abstract}

\section{Objectives and methodology}

The purpose of this article is to draw attention to the changes that have taken place in marketing. During the preparation of the article, we conducted secondary research, which was prepared based on national and international literature and journals. The traditional (GDL) approach to marketing, which put the product at the center of the market, is presented below. In the rest of our article, we would like to present in more detail the path leading to the formation of SDL. In addition, we also describe the differences between the two models and then draw attention to some of the shortcomings of the latter. We also present possible solution alternatives that facilitate the practical application of the view. Finally, we briefly address the future of SDL and draw the necessary conclusions based on the literature studied.

\footnotetext{
* Corresponding author: zsigmondt@,ujs.sk
} 


\section{From the traditional (GDL) approach to SDL}

A long way has led to the development of service marketing. In 1960, McCarthy [1], created his 4 P's (product, price, place, promotion) model. He based his idea on research conducted in the U.S. consumer durables market. The model has become so popular that its use has been extended to almost all product types. The focus of marketing was on the product. In 1981, Booms and Bitner [2], created the 7 P's, which is improved version of the model interpreted for services, completing it with factors of people, process, and physical appearance.

However, this did not bring much change, as the focus was still on the output produced by the company rather than the consumer. The shortcoming of this theory was that it focused only on how a particular service could be sold. It distinguished services from products only on the basis of their external features [3-6].

The previously used model, which focused on the product, was only partially usable and not generalizable, and its use was considered to be outdated by some professionals. Admitting these shortcomings, more and more professionals expressed their dissatisfaction. They were convinced of the need for a paradigm shift in marketing $[7,8]$. As a result, service marketing came to the forefront of attention and became an independent science in the 1980s. In the 1990s, other professionals urged change - e.g. [9-11], etc. New research had already recognized that consumers also had a key role to play in processes. The work of the researchers was facilitated by the spread of the Internet, which made it easier to communicate, access databases and thus carry out scientific work. The change of approach was eventually brought about by two American researchers (Lusch and Vargo) who were already working in the 1990s to create a new concept that would replace the previous approach. In their study, the new theory differs significantly from the above-mentioned model. Lusch and Vargo called the practice that had been used until then Goods-dominant logic, suggesting that only the product was at the heart of the approach. Some authors refer to this trend as Productdominant logic (PDL) in their research (e.g., $[12,13])$. However, this is only a terminological difference, as it includes the same meaning [3, 14, 15, 17].

The newly developed approach (SDL) already emphasizes the importance of co-creation of values, relationships, and process orientation. According to the theory, consumers are already actively involved in value creation, i.e. value is produced by them - in contrast, companies are no longer the value creators, but merely their helpers. According to Ercsey [17] the essence of the SDL concept is that consumer value is created by the customer during the interactions between the service provider and the customer, the company can only make a value proposition. According to Lusch and Vargo, it is worthwhile to examine service marketing as a separate topic, since in the 2000s, services accounted for two-thirds of the GDP of developed countries. Furthermore, for some tangible products, various ancillary services have become increasingly important $[14,18]$.

The pair of authors initially formulated 8 fundamental premises in their study. They were later supplemented by two more basic items. The 10 premises are as follows:

- The service is based on the exchange of competencies.

- Large bureaucratic corporate organizations cover up the original exchange.

- The product is an intermediary in the distribution of the objectified service.

- Knowledge is the basic source of competitive advantage.

- Every economy is service-based.

- It is necessary to involve all stakeholders in interactive, mutual value creation.

- The company cannot add value, only value offers.

- Service focus is consumer and relationship oriented.

- All social and economic actors are resource integrators.

- The value is always determined by the beneficiary individually and in a case-specific way $[14,15,19,20]$. 
Merz et al [3] examined the development of theories related to brand building. In the course of their work, they concluded that there is a link between recent theories on branding and the development of SDL. The current period of branding (2005 and beyond) is already focused on stakeholders. While in earlier periods the brand was seen as serving to identify the company, today it is treated as a dynamic and social process, so the focus is not on the product but on the process. The brand is the result of joint creation. Consumers are no longer seen as an exogenous but an endogenous element in branding. Furthermore, based on the new perception, the brand no longer appears as a passive but an active resource. This shift in attitudes in the field of branding is the same as the shift in marketing in general - the shift towards SDL.

Today, SDL has spread mainly in England and the Scandinavian countries. According to Boenigk et al. [21], its application may also be ideal for non-profit organizations, as in their case consumers and the joint thinking and value creation with them have a key role. Furthermore, suggestions for SDL application were made in areas such as hospitality [22], public transport [20, 23, 24] sales process, logistics [25-27], social marketing [28, 29], and in several other areas as well.

This study by Vargo and Lusch [14] caused a great deal of prominence in the profession. Like any new paradigm, there were supporters and opponents. Their approach was later reworked and supplemented several times. Other experts, such as Anker et al. [12], Baines et al. [13] and critics, such as Grönroos [30], have also begun to delve deeper into the new approach [14, 19, 31-34].

\section{The relationship between SDL and value chains}

Based on Mentzer et al. [25], La Londe and Masters [35] and Jones and Riley [36] the essence of value chains was summarized as a group of companies that aim to deliver products. The main task of supply chain management is to deliver products from suppliers to final consumers. Relying on these views, supply chain management is based on the GDL concept. Lusch et al. [37] took a similar view. According to them, GDL's logic is embedded in value chains because they are made up of vertically interconnected organizations that are linked through transactional exchanges. Later, 3-PL companies emerged that provide various services, thus engaging in the supply chain process. These companies increase the price of their products through their services but continue to focus on the tangible product [26-27].

Constantin and Lusch [38] introduced the concepts of active (operant) and passive (operand) resources. Products and passive resources facilitate the flow of active resources (e.g., knowledge, competencies) between organizations. According to the SDL, value chains appear as so-called "co-creation networks". These networks facilitate the transfer of knowledge between participating members and are an essential source of competitive advantage for companies. These networks contribute to the creation of common values and a common value proposition and value in use is created. The process is not finite, as communication continues in use, which is two-way. This allows the company to further develop its product thanks to consumers [26, 27, 39, 40].

Based on Tokman and Beitelspacher [27], this approach reflects modern competition based on a value proposition created jointly by network members. This network provides a better service experience for end consumers, from which the company also benefits, as consumers become more loyal, they spread positive news about the company and promote the brand. In the U.S. mobile phone services market, it is not just individual companies (such as Verizon and AT\&T) that compete, but the common creative networks of these companies as well. 


\section{The main differences between GDL and SDL}

Lusch and Vargo used the original 4 P's model, which is named after McCarthy [1]. It does not deal in more detail with the other 3 elements of the 7 P's model already mentioned, but incorporates some into the four elements. It can also be seen that the authors deliberately emphasize common and reciprocal concepts, thus targeting the priority of the buyer $[4,17]$.

The main differences between the two theories - GDL and SDL - can be summarized in a table. The table below compares the two theories based on 8 criteria. This comparison is attributed to Vargo, and to other professionals, Maglio and Akaka [41].

Table 1. GDL vs. SDL - based on [41 - 148 p.]

\begin{tabular}{|c|c|c|}
\hline $\begin{array}{c}\text { Reason for economic } \\
\text { exchange (transaction) }\end{array}$ & Gtility / value creation & SDL \\
\hline Subject of economic exchange & Goods (products or services) & $\begin{array}{c}\text { Service as applied knowledge } \\
\text { (competencies and skills) }\end{array}$ \\
\hline Value creation & $\begin{array}{c}\text { Value is created by } \\
\text { companies }\end{array}$ & $\begin{array}{c}\text { Value is created by } \\
\text { companies, consumers and } \\
\text { other stakeholders working } \\
\text { together }\end{array}$ \\
\hline Value creator & $\begin{array}{c}\text { Company, often with inputs } \\
\text { from other companies within } \\
\text { the supply chain (and } \\
\text { sometimes consumers as } \\
\text { "external sources") }\end{array}$ & $\begin{array}{c}\text { Company, network partners } \\
\text { and consumers }\end{array}$ \\
\hline Duty of the companies & $\begin{array}{c}\text { to generate and distribute the } \\
\text { value }\end{array}$ & $\begin{array}{c}\text { Provision of services with } \\
\text { resource integration (value } \\
\text { proposition) }\end{array}$ \\
\hline Consumers' task & $\begin{array}{c}\text { to use the value produced by } \\
\text { companies }\end{array}$ & $\begin{array}{c}\text { to create value together } \\
\text { through resource integration }\end{array}$ \\
\hline Task of the goods & to be embedded in value \\
during manufacturing & $\begin{array}{c}\text { The service serves as a } \\
\text { "means of transport" } \\
\text { (manifestation of the service) }\end{array}$ \\
\hline raw materials are used & $\begin{array}{c}\text { They affect other resources } \\
\text { (eg skills and knowledge) }\end{array}$ \\
\hline
\end{tabular}

It is clear from the table that, according to GDL, the purpose of the transaction is to generate some value. The focus is on the good (product or service), the value is produced by the companies, while the consumers only use it. The main task of the goods is to be incorporated into the concept of value during production. The GDL approach, by the term of "resources", refers mainly to raw materials, whereas in the SDL approach, the main purpose of the transaction is to create some value together. The focus is on service as applied knowledge. Value creation is not the sole responsibility of companies, in fact they only offer the value. Consumers are no longer merely responsible for consumption, as they are also actively involved in the value creation process. And the main resources - e.g. skills, knowledge - affect other resources [41].

In addition to criticisms of practical implementation, a number of different practical solutions have emerged. Of these, the theory of non-profits should be mentioned. 


\section{The shortcomings of SDL}

Based on previous research and theories, SDL had many supporters, but also opponents. The debate over the model is still ongoing in the literature. Such a long "model debate" is a bit unusual in the field, but it is a sign that this model has not been perfectly integrated into the marketing system to date. While in the case of GDL the individual methods have already proved their worth in practice, an appropriate framework has not yet been developed for SDL. Thus, the biggest shortcoming of SDL is that the developed samples, which work well in theory, have not been tested by empirical methods. SDL is difficult to put into practice, mainly due to the well-functioning, simple model of the 4 P's. While the previous approach focuses on developing a marketing strategy, SDL focuses on market processes, its phenomena, and their explanations. SDL consists of premises (basic theorems), which listed earlier - are difficult to understand, mainly without practical examples $[4,18]$.

Table 2. Practical problems and possible solutions for SDL - based on the indicated sources

\begin{tabular}{|c|c|}
\hline $\begin{array}{l}\text { Problems with the practical application of } \\
\text { SDL }\end{array}$ & Suggested solutions \\
\hline The complexity of the basic premises. & $\begin{array}{l}\text { Creating an easier-to-follow model that } \\
\text { includes key steps from consumer } \\
\text { engagement to shared value creation. }\end{array}$ \\
\hline Identification of consumer competencies. & \multirow{3}{*}{$\begin{array}{l}\text { Social media and online or even offline } \\
\text { forums can provide space for the } \\
\text { identification and involvement of consumer } \\
\text { competencies. }\end{array}$} \\
\hline $\begin{array}{l}\text { Consumer involvement - especially for } \\
\text { companies that do not have customer service. }\end{array}$ & \\
\hline Interactive processes [30] & \\
\hline $\begin{array}{l}\text { Managing consumers who do not want to } \\
\text { explore their competence, do not want to be } \\
\text { part of the process, thus they do not participate } \\
\text { in resource allocation and value creation. }\end{array}$ & $\begin{array}{l}\text { Participation, shared value creation is the } \\
\text { consumer's choice, mass-personalized } \\
\text { products still seem appropriate for this } \\
\text { segment. }\end{array}$ \\
\hline Shared value creation in practice [30] & \multirow{2}{*}{$\begin{array}{l}\text { Co-creation begins with the involvement of } \\
\text { the consumer, followed by the integration of } \\
\text { consumer competencies into corporate } \\
\text { resources. Different strategies need to be } \\
\text { developed for different target groups } \\
\text { (including other service providers). }\end{array}$} \\
\hline $\begin{array}{c}\text { Managing consumers from a management } \\
\text { perspective. }\end{array}$ & \\
\hline $\begin{array}{c}\text { Personalization and adaptation vs. cost } \\
\text { efficiency [4] }\end{array}$ & $\begin{array}{l}\text { A balance needs to be struck according to } \\
\text { consumer needs. }\end{array}$ \\
\hline
\end{tabular}

According to SDL theory, consumers are actively involved in processes, so there is no value creation without the presence of consumers. This assumption has now become questionable due to large-scale technological innovations. Technological innovations have made communication easier, but they are increasingly focusing on different ways of communicating less personally, on electronic, Internet platforms. As a result, companies can involve their consumers in the processes relatively easily. In some cases, for example, the consumer virtually enters the company's business. However, this also requires the development of the appropriate technological and physical background. On the other hand, this is not discussed in theory. Furthermore, the model does not take into account the development of organizational processes and other activities that are outside the consumer perspective $[4,15]$.

Instead of the overly complex premises already listed, a simpler model should be created. Online interfaces or even some offline forums can be of great help in recognizing the 
competence of consumers, and they could help to involve consumers even more in the processes. For example, when launching a campaign, consumers can give the company product ideas about its products (new design, patterns, features etc.) and then the winning idea - that even consumers can vote for, for example with the "like" features used on online interfaces - will be put into practice. However, not all consumers want to be involved in the value creation process, so mass-tailored products may be right for them. Consumers need to be managed; different strategies need to be developed for different groups. Personalization is not cost-effective in many cases, but this can be compensated by pricing [4].

\section{The present and future of SDL}

Lovelock and Gummesson [42] stated in their study that service marketing actually defeated traditional product marketing. However, based on the article by Kenesei and Kolos [18], the traditional tools of service marketing should not be discarded - it is worth using them for certain products. Fisk and Grove [43] believe that service marketing has been replaced by traditional marketing thinking, and thus the common principles that both "worlds" products and services - have adopted. According to Brodie et al. [44], well-functioning companies do not stick to one approach at a time, but use them in a blended way, taking advantage of the benefits and taking into account feasibility [45].

Since the 2004 study by Vargo and Lusch, countless articles have been written on the subject. The authors also continued to work on the theory. The 8 premises originally defined have also been further expanded. In addition, other researchers including Kelemen-Erdős [4], Anker et al. [12], Baines et al. [13], Veres [15], Boenigk et al. [21] and Grönroos [30] also dealt with the subject. It is expected that there will be more or less improvements in the future. Vargo and Lusch [34] express in their study that they initially outlined only an incompletely developed version of the SDL model. The authors claim that this was deliberately formed in this way, as at the beginning they had no idea about which direction they should exactly go. Furthermore, they wanted the theory not only to copy their own way of thinking, but also to be further developed by different professionals and academics.

\section{Conclusion}

The SDL approach has brought changes to marketing. The theory puts the service at the center, but also the consumer. The latter is the one who creates consumer value while companies are simply bidding on how they want to meet those needs. Today, consumer needs and interests have become very important for companies. This is due to different new business approaches, consumer advocacy groups, aspirations, and growing moral expectations of companies. Because of this, we believe that SDL may become even more important for companies in the future. However, the theory has sparked major debates in marketing theory. While some supported it, others doubted the theory, and in its feasibility, respectively.

SDL is well-suited for nonprofits, public transportation companies, and is most useful for social marketing. Furthermore, in areas where online consumer communities are present, as they explore consumer habits and use values that are key to innovation, thus important foundations for renewal. As a result, the company creates value with the help of the consumer. The practical implementation of SDL may be hampered in some industries, as its major shortcoming is its limited ability to support corporate strategy. The theory emphasizes the importance of the role of the consumer, but does not address how and how this could be addressed. Furthermore, it does not cover value creation and practical operation. In the future, efforts should be made to get these barriers out of the way of the model. This requires 
professionals to further develop the approach and make it more applicable in practice. In the future, the SDL model needs to be simplified and promoted so that companies are aware of its operation and benefits. It is also worth taking advantage of the potential of online platforms, which were not yet as widespread in the development of the original concept as they are today. All of this would make it easier to involve consumers in each process, which is one of the main goals of SDL. We hope that more researchers will address the topic in the future, leading to newer and better solutions - practical and not just theoretical. The original creators of the theory (Vargo and Lusch) also encourage their colleagues to further explore the topic. In their view, most of the work is already waiting for the next generation.

The research team would like to express its gratitude to our institution, J. Selye University, supporting the research activity of the team.

\section{References}

1. E. J. McCarthy, Basic marketing: a managerial approach, (Homewood:R.D. Irwin, 1960)

2. B. H. Booms, M. J. Bitner, Marketing strategies and organization structures for service firms, In: Marketing of Services, American Marketing Association, Chicago, 47-51 (1981)

3. M. A. Merz, Yi He, S. L. Vargo, J. Acad. Mark. Sci., 37, 3 (2009)

4. A. Kelemen-Erdős, Föszerepben a fogyasztó? A service-dominant logic elmélet kritikus megközelitése, in Proceedings: Az Egyesület a Marketing Oktatásáért és Kutatásáért XXI. országos konferenciájának tanulmánykötete, 125-135 (2015)

5. A. Graa, S. Abdelhak, Acta Oeconomica Universitatis Selye (AOUS), 5(1), 67-72 (2016)

6. L. Khúlová, Acta Oeconomica Universitatis Selye (AOUS), 5(1), 85-95 (2016)

7. A. L. Page, M. Siemplenski, Product Systems Marketing, Ind. Mark. Manag., 12(2) (1983)

8. A. Giddens, The constitution of society, (Berkeley: University of California Press, 1984)

9. E. Gummesson, Relationship Marketing: Its Role in the Service Economy, In: Understanding Services Management: Integrating Marketing Organisational Behaviour, Operations and Human Resource Management, 244-267 (1995)

10. R. Rust, J. Serv. Res., 1(2), 107 (1998)

11. R. S. Achrol, P. Kotler, J. Mark., 63(4_suppl1), 146-163 (1999)

12. T. B. Anker, L. Sparks, L. Moutinho, C. Grönroos, Eur. J. Mark., 49, 3/4, 532-560 (2015)

13. C. Baines, C. Fill, K. Page, Essentials of Marketing, (Oxford University Press, 2013)

14. S. L. Vargo, R. F. Lusch, J. Mark., 68(1), 1-17 (2004)

15. Z. Veres, Az értékteremtés ,,service-dominant” logikája, A Széchényi István Egyetem Kautz Gyula Gazdaságtudományi Kar és a Regionalis- és Gazdaságtudományi Doktori Iskola szervezésében megrendezésre kerülő konferencia kiadványa, 5-22 (2012)

16. P. Marinič, Customer Satisfaction and Financial Performance, in Proceedings of 3rd International Multidisciplinary Scientific Conference on Social Sciences and Arts SGEM 2016, 229-236 (2016) 
17. I. Ercsey, Vevői involvement generációs kitekintésben, "Ifjúság - jövőképek": Kautz Gyula Emlékkonferencia (2017)

18. Zs. Kenesei, K. Kolos, Vezetéstudomány - Budapest Management Review, 49(1), 2-12 (2018)

19. S. L. Vargo, R. F. Lusch, J. Acad. Mark. Sci. Rev. 36, 1-10 (2008)

20. A. Kelemen-Erdős, M. Vágási, Érintettek bevonása a fenntartható közösségi közlekedésfejlesztésbe - A service-dominant logic alkalmazása a szolgáltatásinnovációban, in: Vállalkozásfejlesztés a XXI. században, 177-196 (2016)

21. S. Boenigk, B. Helmig, M. Bruhn, K. Hadwich, V. Batt, An empirical investigation of experiences and the link between a service-dominant logic mindset, competitive advantage, and performance of nonprofit organizations, In book: Customer Experience, 439-499 (2012)

22. A. Kelemen-Erdős, A. Mitev, Kocsma-érték-Szolgáltatásérték-teremtés a vendéglátásban - Az art-és romkocsmák példája, in: Tükröződés, társtudományok, trendek, fogyasztás, 45-54 (2017)

23. M. Alexander, E. Jaakkola, Customer Engagement Behaviours and Value Co-creation, in book: Customer Engagement: Contemporary Issues and Challenges, 3-20 (2015)

24. A. Schäfer, J. Klammer, Management, 11(3), 255-264 (2016)

25. J. T. Mentzer, D. J. Flint, G. T. Hult, J. Mark., 65(4), 82-104 (2001)

26. A. Yazdanparast, I. Manuj, S. M. Swartz, Int. J. Logist. Manag., 21(3), 375-403 (2010)

27. M. Tokman, L. S. Beitelspacher, Int. J. Phys. Distrib. Logist. Manag., 41(7), 717-726 (2011)

28. R. Russell-Bennett, M. Wood, J. Soc. Mark., 3(3), 223-238 (2013)

29. N. R. Luca, S. Hibbert, R. McDonald, Mark. Theory, 16(2), 194-218 (2015)

30. C. Grönroos, Mark. Theory, 11(3), 279-301 (2011)

31. S. L. Vargo, R. F. Lusch, Service-dominant logic as a foundation for a general theory, In book: The service-dominant logic of marketing: Dialog, debate, and directions, 406420 (2006)

32. R. F. Lusch, S. L. Vargo, Service-dominant logic: Premises, perspectives, possibilities, (Cambridge University Press, 2014)

33. S. L. Vargo, R. F. Lusch, J. Acad. Mark. Sci. 44, 5-23 (2016)

34. S. L.Vargo, R. F. Lusch, Int. J. Res. Mark. 34(1), 46-67 (2017)

35. B. J. La Londe, J. M. Masters, Int. J. Phys. Distrib. Logist. Manag. 24(7), 35-47 (1994)

36. T. C. Jones, D. W. Riley, Int. J. Phys. Distrib. Logist. Manag., 15(5), 16-26 (1985)

37. R. F. Lusch, S. L. Vargo, J. Retail., 83(1), 5-18 (2007)

38. J. A. Constantin, R. F. Lusch, Understanding resource management: how to deploy your people, products and processes for maximum productivity, (Oxford: The Planning Forum,1994)

39. M. Sołtysik, M. Zakrzewska, A. Sagan, S. Jarosz, Educ. Sci. 10(5), 146 (2020)

40. M. Zakrzewska, S. Jarosz, M. Sołtysik, Scientific Papers of Silesian University of Technology - Organization \& Management Series 148, 811- 823 (2020)

41. S. L. Vargo, R. P. Lusch, M. A. Akaka, Eur. Manag. J., 26(3), 145-152 (2008)

42. C. Lovelock, E. Gummesson, J. Serv. Res., 7(1), 20-41 (2004) 
43. R. P. Fisk, S. J. Grove, The evolution and future of the service: Building and broadening a multidisciplinary field, in Handbook of service science: Research and innovations in the service economy, 643-663 (2010)

44. R, J. Brodie, N. E. Coviello, H. Winklhofer, J. Bus. Ind. Mark., 23(2), 84-94 (2008)

45. D. Polónyi Karaffová, A. Kusá, Acta Oeconomica Universitatis Selye, 7(2), 122-140 (2018) 